\title{
Production of Cocktail Enzymes by Three Cladosporium Isolates and Bioconversion of Orange Peel Wastes into Valuable Enzymes
}

\author{
Ahmad Mohamed Moharram ${ }^{1,2}$, Abdel-Naser Ahmed Zohri ${ }^{1}$, \\ Abd El-Latif Hesham ${ }^{3}$ (D), Mohamed Al-Ameen Maher ${ }^{1}$ and \\ Osama Abdel-Hafeez Mohamed Shaban Al-Bedak* \\ ${ }^{1}$ Department of Botany and Microbiology, Faculty of Science, Assiut University 71526, Assiut, Egypt. \\ ${ }^{2}$ Assiut University Mycological Centre, Assiut University 71526, Assiut, Egypt. \\ ${ }^{3}$ Department of Genetics, Faculty of Agriculture, Beni-Suef University 62521, Beni-Suef, Egypt.
}

\begin{abstract}
The current research demonstrates the biotechnological economization of accumulated and inefficiently used agro-industrial orange peel wastes to generate amylase, endoglucanase, exoglucanase, pectinase, and xylanase, industrially essential enzymes with growing demands in enzyme markets, from three Cladosporium isolates. In submerged fermentation (SmF) at $10^{\circ} \mathrm{C}$, the isolate AUMC 10865 produced the highest level of amylase (4164 IU/gram dry substrate). Endoglucanase, exoglucanase and xylanase had development peaks (923 IU/gds, $2280 \mathrm{lU} / \mathrm{gds}$, and $1646 \mathrm{IU} / \mathrm{gds}$, respectively in case of Cladosporium sp. AUMC 11366. Pectinase produced the most (7840 IU/gds) in the strain AUMC 11340 . At $30^{\circ} \mathrm{C}$, the strain AUMC 11340 secretes the most amylase (4120 IU/gds), endoglucanase ( $2700 \mathrm{lU} / \mathrm{gds}$ ) and xylanase ( $3220 \mathrm{IU} / \mathrm{gds})$. Exoglucanase development reached the peak ( $8750 \mathrm{lU} / \mathrm{gds}$ ) in the isolate AUMC 10865. The overall production ( $5570 \mathrm{lU} / \mathrm{gds}$ ) was instead enhanced by pectinase in the AUMC 11366 isolate. In solid-state fermentation (SSF) at $10^{\circ} \mathrm{C}$, the isolate AUMC 10865 outperformed the other two isolates producing $640.0 \mathrm{IU} / \mathrm{gds}$ amylase, $763.3 \mathrm{IU} / \mathrm{gds}$ endoglucanase, $771.0 \mathrm{IU} / \mathrm{gds}$ exoglucanase, $1273.23 \mathrm{IU} /$ gds pectinase and $1062.0 \mathrm{lU} / \mathrm{gds}$ xylanase, while the isolate AUMC 11366 produced the least amount of $399.7 \mathrm{IU} / \mathrm{gds}, \mathbf{4 1 0 . 0} \mathrm{IU} / \mathrm{gds}, \mathbf{4 1 3 . 3} \mathrm{IU} / \mathrm{gds}, \mathbf{5 5 8 . 7} \mathrm{IU} / \mathrm{gds}$, and $548.0 \mathrm{IU} / \mathrm{gds}$, respectively. At $30^{\circ} \mathrm{C}$, the isolate AUMC 11340 was superiorly producing higher levels of amylase ( $973.3 \mathrm{lU} / \mathrm{gds})$, endoglucanase (746.0 IU/gds), exoglucanase (1052.0 IU/gds), pectinase (1685.3 IU/gds) and xylanase (1340.0 IU/gds), whereas isolate AUMC 10865 generated the least amounts of amylase (556.7 IU/gds) and exoglucanase (452.7 IU/gfs), and the isolate AUMC 11366 produced the least endoglucanase (256.3 IU/gds), pectinase (857.7 IU/gfs) and xylanase (436.3 IU/gds) amounts.
\end{abstract}

Keywords: Agro-industrial, Bioconversion, Cladosporium, Enzymes, Fermentation

*Correspondences: osamaalbedak@gmail.com; hesham_egypt5@agr.bsu.edu.eg

(Received: August 20, 2021; accepted: October 25, 2021)

Citation: Moharram AM, Zohri AA, Hesham AE, Maher MA, AI-Bedak OAMS. Production of Cocktail Enzymes by Three Cladosporium Isolates and Bioconversion of Orange Peel Wastes into Valuable Enzymes. J Pure Appl Microbiol. 2021;15(4):23362346. doi: 10.22207/JPAM.15.4.58

(C) The Author(s) 2021. Open Access. This article is distributed under the terms of the Creative Commons Attribution 4.0 International License which permits unrestricted use, sharing, distribution, and reproduction in any medium, provided you give appropriate credit to the original author(s) and the source, provide a link to the Creative Commons license, and indicate if changes were made. 


\section{INTRODUCTION}

Cladosporium is amongst the largest and diverse hyphomycetes, with more than 772 names. ${ }^{1}$ Cladosporium was previously used to refer to all unrelated dematiaceous hyphomycetes with amero-to-phragmosporous conidia produced in acropetal chains. Cladosporium species are well suited to disperse in vast numbers over long distances, so they are cosmopolitan and commonly found in all forms of plants, and other debris, often isolated from air, soil, crops, grains, fruit, paint, textiles, and other organic matter. ${ }^{1-9}$ Some species of this genus are plant pathogenic causing leaf spots and other lesions, ${ }^{10}$ or they occur as hyper parasites on other fungi. ${ }^{11}$

Active research on converting agricultural by-products into value-added products has been purposed to produce different enzymes of great economic value. Orange juice is now one of the best drinks in the world ${ }^{12,13}$ and orange is one of Egypt's important commercial crops. ${ }^{14}$ The production of orange juice is made with a large percentage of citrus fruits, of which around $50 \%$ to $60 \%$ is converted into citrus peel wastes, ${ }^{15,16}$ which leads to the accumulation of large quantities of peel waste in the citrus processing industries. Important quantities have been collected of orange peel waste along with environmental issues to ensure that health risks arising from unsatisfactory treatment practices meet the essential needs for identifying alternative biotechnological waste recycling options. ${ }^{17,18}$

In accordance with existing law on the environment, any wastes can be used as an ingredient for recycling. ${ }^{19}$ The use of orange peel as a potentially useful low-cost resource will provide high quality goods. ${ }^{12,18,20}$ The literature extensively describes a variety of promising approaches for effective use of orange peel wastes. Consequently, three Cladosporium isolates were used for biosynthesis of some important enzymes in submerged fermentation (SmF) and their enzymatic ability was used through solid-state (SSF) methods in order to bio-convert orange peel wastes as a low-cost substrate into valuable enzymes.

\section{MATERIALS AND METHODS \\ Isolation and Maintenance of Cladosporium Isolates}

Three Cladosporium isolates involved in the current study, of which two were isolated from air of Beni Suef and Qena cities and one from grapevine fruits in Sohag city, Egypt. Exposure method ${ }^{21}$ was employed for isolation of Cladosporium from air and direct plating technique 22 for isolation from grapevine fruits. Czapek's Dox agar was used as an isolation medium. The medium is composed of $(\mathrm{g} / \mathrm{L})$ : Sucrose, 30; $\mathrm{Na}_{2} \mathrm{NO}_{3}, 2 ; \mathrm{K}_{2} \mathrm{HPO}_{4}, 1 ; \mathrm{KCl}, 0.5$; $\mathrm{MgSO}_{4} .7 \mathrm{H}_{2} \mathrm{O}, 0.5 ; \mathrm{FeSO}_{4^{\prime}} 0.01 ; \mathrm{ZnSO}_{4^{\prime}}, 0.01 ; \mathrm{CuSO}_{4^{\prime}}$ 0.005; Rose Bengal, 0.05; chloramphenicol, 0.25; agar, 15 and the final $\mathrm{pH}$ 7.3. Interesting isolates obtained were preserved as frozen and lyophilized cultures, as well as on cotton ball ${ }^{23}$ in the culture collection of Assiut University Mycological Centre as AUMC 10865 (air, Beni-Suef), AUMC 11340 (grapevine fruits, Sohag) and AUMC 11366 (air, Qena).

Molecular Identification of the Cladosporium Isolates

DNA Extraction, PCR and Sequencing of Internal Transcribed Spacer (ITS) Gene

For DNA isolation, a small portion from fungal growth of 7-day-old colonies of Cladosporium isolates AUMC 10865, AUMC 11340 and AUMC 11366 grown on potato dextrose agar (PDA) at $25^{\circ} \mathrm{C}$ were collected and transferred individually to $2 \mathrm{ml}$-Eppendorf tube. The DNA extraction was performed following CTAB method described in Moubasher et al. ${ }^{24}$ The universal primers ITS1 and ITS $4^{25}$ were used for amplification of the internal transcribed spacer (ITS) region. ${ }^{26,9}$ Alignment and Phylogenetic Analysis

The sequences of Cladosporium isolates in this study were compared to the closely related sequences in GenBank as well as sequences of the type and ex-type Cladosporium species. Sequences of Cladosporium isolates in this study and those retrieved from GenBank were aligned together using MAFFT (version 6.861b) with the default options. ${ }^{27}$ Alignment gaps and parsimony uninformative characters were cleaned using BMGE. ${ }^{28}$ Maximum-likelihood (ML) and Maximum 
parsimony (MP) phylogenetic analyses were performed using PhyML 3.0. ${ }^{29}$ The robustness of the most parsimonious trees was evaluated by 100 bootstrap replications. ${ }^{30,31}$ The best optimal model of nucleotide substitution for the ML analyses was determined using Smart Model Selection (SMS) version 1.8.1. ${ }^{32}$ The phylogenetic tree was drawn using MEGAX, ${ }^{33}$ and edited using Microsoft Power Point (2016) and saved as TIF file. ${ }^{9}$

\section{Assessment of Enzymatic Potential in Submerged Fermentation (SmF)}

Cladosporium AUMC 10865, AUMC 11340 and AUMC 11366 were cultivated, separately in $250 \mathrm{ml}$ Erlenmeyer conical flasks containing $50 \mathrm{ml}$ sucrose-free Czapek's broth medium supplemented with $1 \%$ soluble starch (for amylase production) or $1 \%$ pectin (for pectinase) or $1 \%$ xylan (for endoglucanase, exoglucanase and xylanase production). The flasks were inoculated, individually with $1 \mathrm{ml}$ containing $1.8 \times 10^{8}$ spore/ $\mathrm{ml}$ of spore suspension obtained from 7-day-old cultures of the Cladosporium isolates tested. The flasks were then incubated for 7 days at $10^{\circ} \mathrm{C}$ and $30^{\circ} \mathrm{C}$ in shacking condition at $120 \mathrm{rpm}$. After incubation, the fermented media were filtered through Whatman No.1 filter paper and the cellfree supernatants obtained by centrifugation (10000 $\mathrm{xg}$ at $4^{\circ} \mathrm{C}$ for $10 \mathrm{~min}$ ) were used as enzyme sources.

\section{Enzymes Assay and Protein Estimation}

Starch, carboxymethyl cellulose (CMC), microcrystalline cellulose (avicel), pectin, and oat spelts xylan were used for assays of amylase, endoglucanase, exoglucanase, pectinase and xylanase respectively. The reaction mixture consists of $0.5 \mathrm{ml}$ of the filtered crude enzyme and $0.5 \mathrm{ml}$ of previously-mentioned substrates at a concentration of $1 \%$ (prepared in $50 \mathrm{mM} \mathrm{Na}$ citrate buffer, $\mathrm{pH}$ 5.0). The reaction was carried out in water bath at $50^{\circ} \mathrm{C}$ for $20 \mathrm{~min}$. Afterwards, the process was stopped by introducing $2 \mathrm{ml}$ of 3 , 5-dinitrosalicylic acid (DNS) and the tube contents were placed in a boiling water bath for $10 \mathrm{~min}^{34}$ After cooling, the color absorbance was measured at $540 \mathrm{~nm}$ using UV-Visible spectrophotometer (T80+; UK). The amount of reducing sugar liberated was quantified using standard curves of glucose (for amylase, endoglucanase, exoglucanase, and pectinase), or xylose (for xylanase). One unit of the enzyme is defined as the amount of enzyme that liberates $1 \mu \mathrm{mol}$ of the reducing sugar (glucose or xylose) equivalent per minute under the standard assay conditions. ${ }^{35}$ Total protein content was measured by using bovine serum albumin (BSA) as the standard ${ }^{36}$ Calculations of enzyme activities were done. ${ }^{37,38}$

Bioconversion of Orange Peel Wastes into Cocktail Enzyme

Determination of Moisture Content (MC) of Orange Peels

Twenty grams of orange peels were weighed and dried in an oven at $105^{\circ} \mathrm{C}$ over-night, then cooled in a desiccator for 30 minutes and reweighed. The moisture content was calculated as follows:

$\% \mathrm{MC}=\frac{\text { wt.of wet sample-wt.of dry sample }}{\text { wt.of wet sample }} \times 100$

\section{Solid-State Fermentation}

Cladosporium isolates were grown separately in Erlenmeyer flasks containing 10

Table 1. Production and specific activity of amylase, endoglucanase, exoglucanase, pectinase and xylanase enzymes produced by Cladosporium isolates AUMC 10865, AUMC 11340 and AUMC 11366 in SmF at $10^{\circ} \mathrm{C}$

\begin{tabular}{|c|c|c|c|c|c|c|}
\hline \multirow[t]{2}{*}{$\begin{array}{l}\text { Extracellular } \\
\text { enzymes }\end{array}$} & \multicolumn{2}{|c|}{$\begin{array}{l}\text { Cladosporium sp. } \\
\text { AUMC } 10865\end{array}$} & \multicolumn{2}{|c|}{$\begin{array}{l}\text { Cladosporium sp. } \\
\text { AUMC } 11340\end{array}$} & \multicolumn{2}{|c|}{$\begin{array}{l}\text { Cladosporium sp. } \\
\text { AUMC } 11366\end{array}$} \\
\hline & $\begin{array}{l}\text { Production } \\
\text { IU/gds }\end{array}$ & $\begin{array}{c}\text { Specific } \\
\text { activity } \\
\text { IU/mg }\end{array}$ & $\begin{array}{l}\text { Production } \\
\text { IU/gds }\end{array}$ & $\begin{array}{c}\text { Specific } \\
\text { activity } \\
\text { IU/mg }\end{array}$ & $\begin{array}{l}\text { Production } \\
\text { IU/gds }\end{array}$ & $\begin{array}{c}\text { Specific } \\
\text { activity } \\
\text { IU/mg }\end{array}$ \\
\hline$\alpha$-amylase & 4164 & 62.5 & 458 & 0.375 & 235 & 3.2 \\
\hline Endoglucanase & 846 & 2 & 760 & 5.85 & 923 & 4.053 \\
\hline Exoglucanase & 2220 & 5.4 & 1620 & 12.43 & 2280 & 10.9 \\
\hline Pectinase & 4870 & 8 & 7840 & 1.78 & 4690 & 7.52 \\
\hline Xylanase & 1600 & 3.26 & 150 & 0.971 & 1646 & 6.065 \\
\hline
\end{tabular}


$\mathrm{g}$ of fresh orange peel wastes and $10 \mathrm{~mL}$ of fermentation medium. The fermentation medium contained $(\mathrm{g} / \mathrm{L})$ : pectin from citrus peel, 1.0 ; sodium nitrate, 2.0; magnesium sulphate, 0.5 ; di-potassium hydrogen orthophosphate, 1.0; potassium chloride, 0.5 ; zinc sulphate, 0.01 ; and copper sulphate, 0.005 . After autoclaving at $121^{\circ} \mathrm{C}$ for 20 minutes, each flask was inoculated with
$1 \%$ spore suspension obtained from a 7-day-old cultures of the Cladosporium isolates. Two sets of flasks were incubated in stagnant conditions at $10^{\circ} \mathrm{C}$ and $30^{\circ} \mathrm{C}$ for 10 days. Following the incubation period, the contents of each flask were extracted with $100 \mathrm{ml}$ of $50 \mathrm{mM}$ citrate buffer $(\mathrm{pH}$ 5.0), and cell-free supernatants were obtained through centrifugation at $10,000 \mathrm{xg}$ for $10 \mathrm{~min}$. The

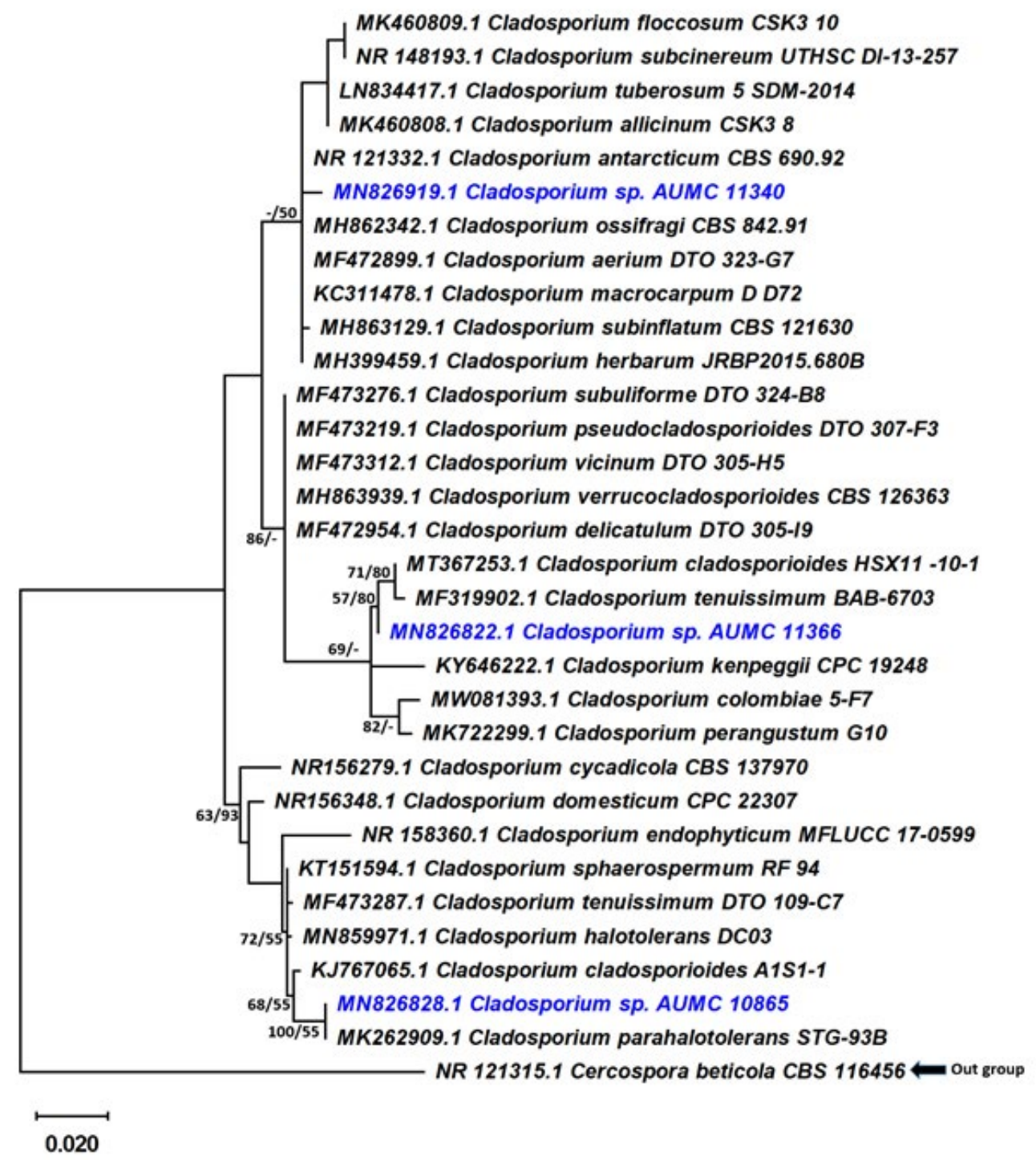

Fig. 1. Phylogenetic tree generated from MP analysis based on alignment of ITS sequences of Cladosporium isolates AUMC 10865, AUMC 11340 and AUMC 11366 with the most similar sequences belonging to Cladosporium in GenBank database. Sequences from this study are in blue color. Bootstrap support values (100 replications) for $\mathrm{ML} / \mathrm{MP}$ combination $\geq 50 \%$ are indicated at the respective nodes. The tree was rooted to Cercospora beticola CBS 116456 as outgroup. 
transparent supernatant was used as a source of cocktail enzymes. As previously stated, the amount of reducing sugar liberated, as well as enzyme activity and soluble protein were calculated.

\section{RESULTS}

\section{Phylogenetic Analyses}

The ITS sequences obtained from 32 strains produced 566 characters of which 494 were complete characters (no gaps, no N), 114 variable characters ( $23.1 \%$ of the complete characters) and 29 characters were parsimony informative $(5.9 \%$ of complete). Tamura-Nei (TN93) was the best nucleotide substitution model. The dataset for maximal parsimony yielded 2 best parsimony trees with a tree length of 136 steps. The strongest ML tree score with a final ML probability optimization value of -1662.15949 and a tree size of 0.40191 was monitored to explain and explore the phylogenetic relationship between taxa (Fig. 1). The ITS sequences of Cladosporium isolates AUMC 10865, AUMC 11340, and AUMC 11366 from this study were uploaded to GenBank as MN826828, MN826919 and MN826822, respectively.

Enzymatic Capability of Cladosporium Isolates in SmF

Using $\mathrm{SmF}$ at $10^{\circ} \mathrm{C}$ and $30^{\circ} \mathrm{C}$, the three Cladosporium isolates could develop amylase,

Table 2. Production and specific activity of amylase, endoglucanase, exoglucanase, pectinase and xylanase enzymes produced by Cladosporium isolates AUMC 10865, AUMC 11340 and AUMC 11366 in SmF at $30^{\circ} \mathrm{C}$

\begin{tabular}{|c|c|c|c|c|c|c|}
\hline \multirow[t]{2}{*}{$\begin{array}{l}\text { Extracellular } \\
\text { enzymes }\end{array}$} & \multicolumn{2}{|c|}{$\begin{array}{l}\text { Cladosporium sp. } \\
\text { AUMC } 10865\end{array}$} & \multicolumn{2}{|c|}{$\begin{array}{l}\text { Cladosporium sp. } \\
\text { AUMC } 11340\end{array}$} & \multicolumn{2}{|c|}{$\begin{array}{l}\text { Cladosporium sp. } \\
\text { AUMC } 11366\end{array}$} \\
\hline & $\begin{array}{l}\text { Production } \\
\text { IU/gds }\end{array}$ & $\begin{array}{c}\text { Specific } \\
\text { activity } \\
\text { IU/mg }\end{array}$ & $\begin{array}{l}\text { Production } \\
\text { IU/gds }\end{array}$ & $\begin{array}{c}\text { Specific } \\
\text { activity } \\
\text { IU/mg }\end{array}$ & $\begin{array}{l}\text { Production } \\
\text { IU/gds }\end{array}$ & $\begin{array}{c}\text { Specific } \\
\text { activity } \\
\text { IU/mg }\end{array}$ \\
\hline$\alpha$-amylase & 3700 & 43.7 & 4120 & 11.9 & 2350 & 6.34 \\
\hline Endoglucanase & 700 & 1.63 & 2700 & 27.8 & 2400 & 17.0 \\
\hline Exoglucanase & 8750 & 1.86 & 1220 & 12.53 & 2370 & 16.8 \\
\hline Pectinase & 2970 & 62.0 & 3820 & 10.64 & 5570 & 2.64 \\
\hline Xylanase & 2690 & 5.32 & 3220 & 28.1 & 2900 & 17.34 \\
\hline
\end{tabular}

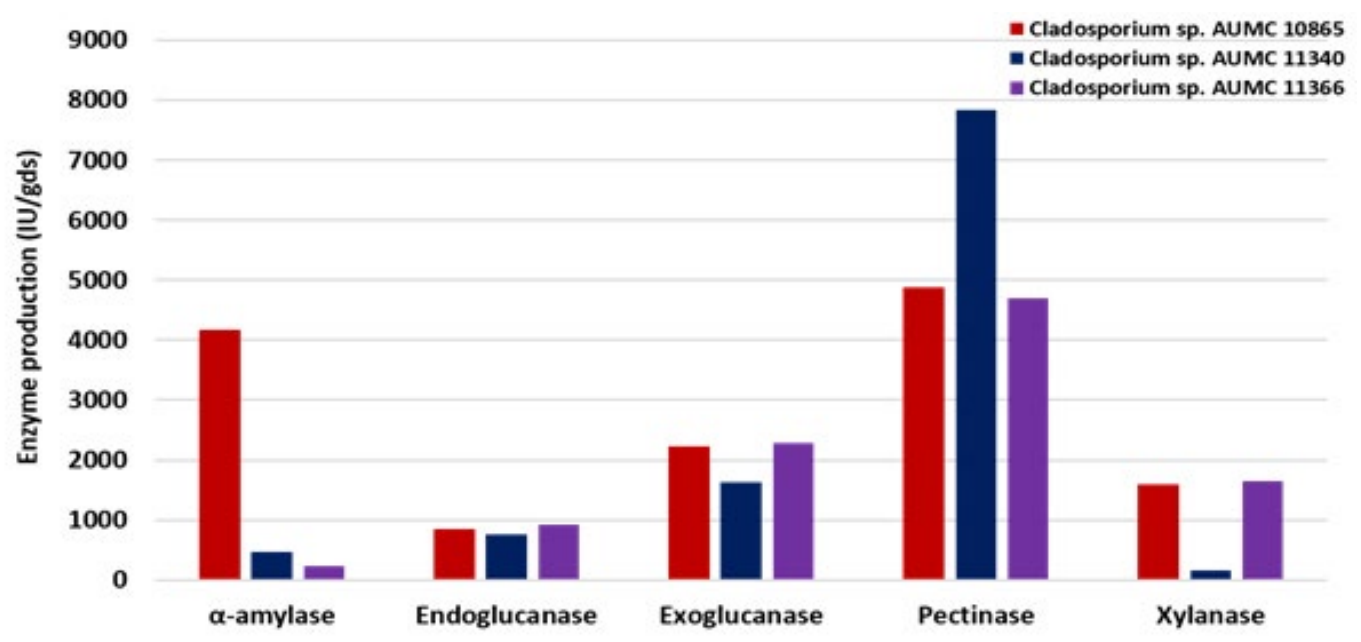

Extracellular enzymes

Fig. 2. Enzymes production (IU/gds) by Cladosporium isolates AUMC 10865, AUMC 11340 and AUMC 11366 at $10^{\circ} \mathrm{C}$ in $\mathrm{SmF}$. 
endoglucanase, exoglucanase, chitinase, pectinase and xylanase enzymes in varied levels of production and activity. At $10^{\circ} \mathrm{C}$, the isolate AUMC 10865 produced the most amylase (4164 IU/gds) and had the highest specific activity (62.5 $\mathrm{IU} / \mathrm{mg}$ ). Endoglucanase and exoglucanase had the development peak (923 IU/gds and $2280 \mathrm{IU} /$ gds, respectively) in the strain AUMC 11366, while both enzymes had the highest specific activity (5.85 IU/mg and $12.43 \mathrm{IU} / \mathrm{mg}$, respectively) in the strain AUMC 11340. Pectinase produced the most (7840 IU/gds) in the strain AUMC 11340 and had the highest specific activity $(8.0 \mathrm{lU} / \mathrm{mg})$ in the strain AUMC 10865. Xylanase reached the maximum production (1646 IU/gds) and specific activity $(6.065 \mathrm{IU} / \mathrm{mg})$ in the strain AUMC 11366 (Table 1; Fig. 2).

On the other hand, using $\mathrm{SmF}$ at $30^{\circ} \mathrm{C}$, the strain AUMC 11340 secretes the most amylase (4120 IU/gds), endoglucanase (2700 IU/ gds) and xylanase (3220 IU/gds) with the peak of specific activity of endoglucanase $(27.8 \mathrm{IU} / \mathrm{mg})$ and xylanase $(28.1 \mathrm{IU} / \mathrm{mg})$, while the maximum specific activity of amylase $(43.7 \mathrm{lU} / \mathrm{mg}$ ) was recorded in the strain AUMC 10865. Exoglucanase development reached the peak (8750 IU/gds) in the strain AUMC 10865 and specific activity (16.8 $\mathrm{IU} / \mathrm{mg}$ ) in the strain AUMC 11366 . The overall production (2860 IU/gds and $5570 \mathrm{lU} / \mathrm{gds}$ ) was instead enhanced by chitinase and pectinase

Table 3. Production and specific activity of amylase, endoglucanase, exoglucanase, pectinase and xylanase enzymes produced by Cladosporium isolates AUMC 10865, AUMC 11340 and AUMC 11366 from untreated orange peels in SSF at $10^{\circ} \mathrm{C}$

\begin{tabular}{|c|c|c|c|c|c|c|}
\hline \multirow[t]{2}{*}{$\begin{array}{l}\text { Extracellular } \\
\text { enzymes }\end{array}$} & \multicolumn{2}{|c|}{$\begin{array}{l}\text { Cladosporium sp. } \\
\text { AUMC } 10865\end{array}$} & \multicolumn{2}{|c|}{$\begin{array}{l}\text { Cladosporium sp. } \\
\text { AUMC } 11340\end{array}$} & \multicolumn{2}{|c|}{$\begin{array}{l}\text { Cladosporium sp. } \\
\text { AUMC } 11366\end{array}$} \\
\hline & $\begin{array}{l}\text { Production } \\
\text { IU/gds }\end{array}$ & $\begin{array}{c}\text { Specific } \\
\text { activity } \\
\text { IU/mg }\end{array}$ & $\begin{array}{l}\text { Production } \\
\text { IU/gds }\end{array}$ & $\begin{array}{c}\text { Specific } \\
\text { activity } \\
\text { IU/mg }\end{array}$ & $\begin{array}{l}\text { Production } \\
\text { IU/gds }\end{array}$ & $\begin{array}{c}\text { Specific } \\
\text { activity } \\
\text { IU/mg }\end{array}$ \\
\hline Amylase & 640.0 & 1.45 & 586.7 & 0.766 & 399.7 & 0.788 \\
\hline Endoglucanase & 763.3 & 1.73 & 661.3 & 0.862 & 410.0 & 0.8 \\
\hline Exoglucanase & 771.0 & 1.75 & 555.3 & 0.724 & 413.3 & 0.814 \\
\hline Pectinase & 1273.23 & 2.88 & 919.7 & 1.2 & 558.7 & 1.1 \\
\hline Xylanase & 1062.0 & 2.0 & 672.0 & 0.87 & 548.0 & 0.9 \\
\hline
\end{tabular}

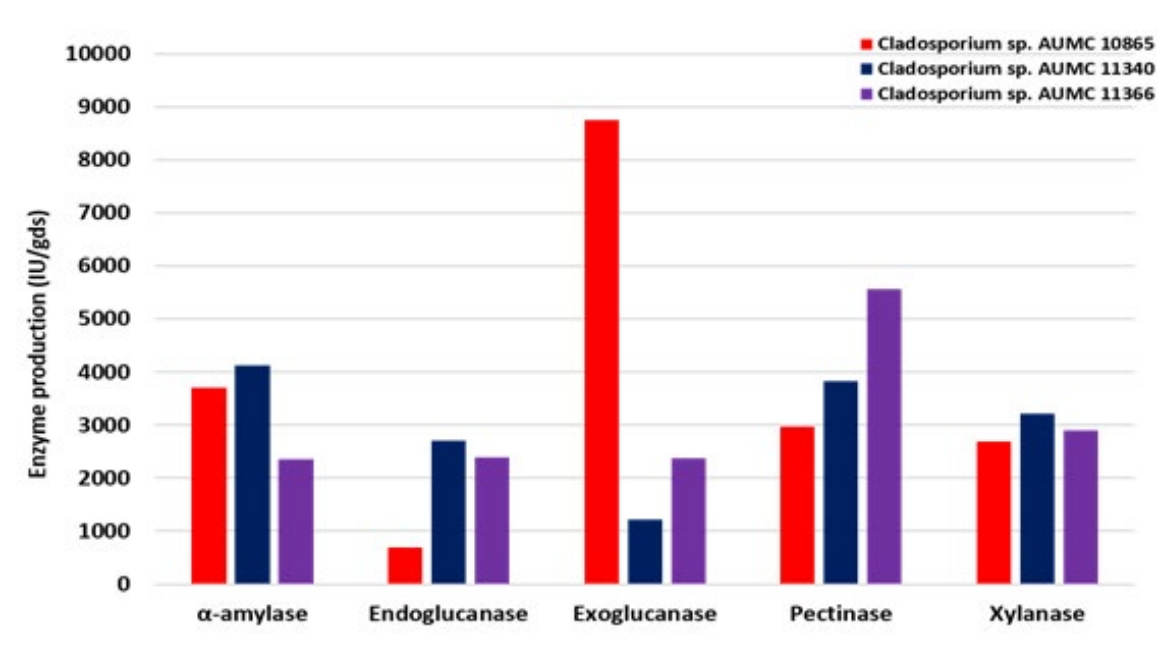

Extracellular enzymes

Fig. 3. Enzymes production (IU/gds) by Cladosporium isolates AUMC 10865, AUMC 11340 and AUMC 11366 at $30^{\circ} \mathrm{C}$ in $\mathrm{SmF}$. 
in the AUMC 11366 strain with the specific activity maximum $(28.4 \mathrm{IU} / \mathrm{mg}$ and $62.0 \mathrm{IU} / \mathrm{mg}$, respectively) in the AUMC 10865 strain (Table 2; Fig. 3).

Bioconversion of Orange peel wastes into Cocktail Enzymes in SSF

The moisture content of the orange peel wastes was found to be $70 \%$. Based on the MC percent, the enzymatic activity was calculated as IU/gram dry substrate (IU/gds). In SSF at $10^{\circ} \mathrm{C}$, the isolate AUMC 10865 outperformed the other two isolates producing $640.0 \mathrm{IU} / \mathrm{gds}$ amylase, $763.3 \mathrm{IU} /$ gds endoglucanase, $771.0 \mathrm{IU} / \mathrm{gds}$ exoglucanase,
$1273.23 \mathrm{IU} / \mathrm{gds}$ pectinase and $1062.0 \mathrm{IU} / \mathrm{gds}$ xylanase, while the isolate AUMC 11366 produced the least amount of $399.7 \mathrm{IU} / \mathrm{gds}, 410.0 \mathrm{IU} / \mathrm{gds}$, $413.3 \mathrm{lU} / \mathrm{gds}, 558.7 \mathrm{IU} / \mathrm{gds}$, and $548.0 \mathrm{IU} / \mathrm{gds}$, respectively (Table 3; Fig. 4).

On the other hand, at $30^{\circ} \mathrm{C}$ the isolate AUMC 11340 was superiorly producing higher levels of amylase (973.3 IU/gds), endoglucanase (746.0 IU/gds), exoglucanase (1052.0 IU/gds), pectinase (1685.3 IU/gds) and xylanase (1340.0 IU/gds), whereas isolate AUMC 10865 generated the least amounts of amylase (556.7 IU/gds) and exoglucanase (452.7 IU/gfs), and the isolate AUMC

Table 4. Production and specific activity of amylase, endoglucanase, exoglucanase, pectinase and xylanase enzymes produced by Cladosporium isolates AUMC 10865, AUMC 11340 and AUMC 11366 from untreated orange peels in SSF at $30^{\circ} \mathrm{C}$

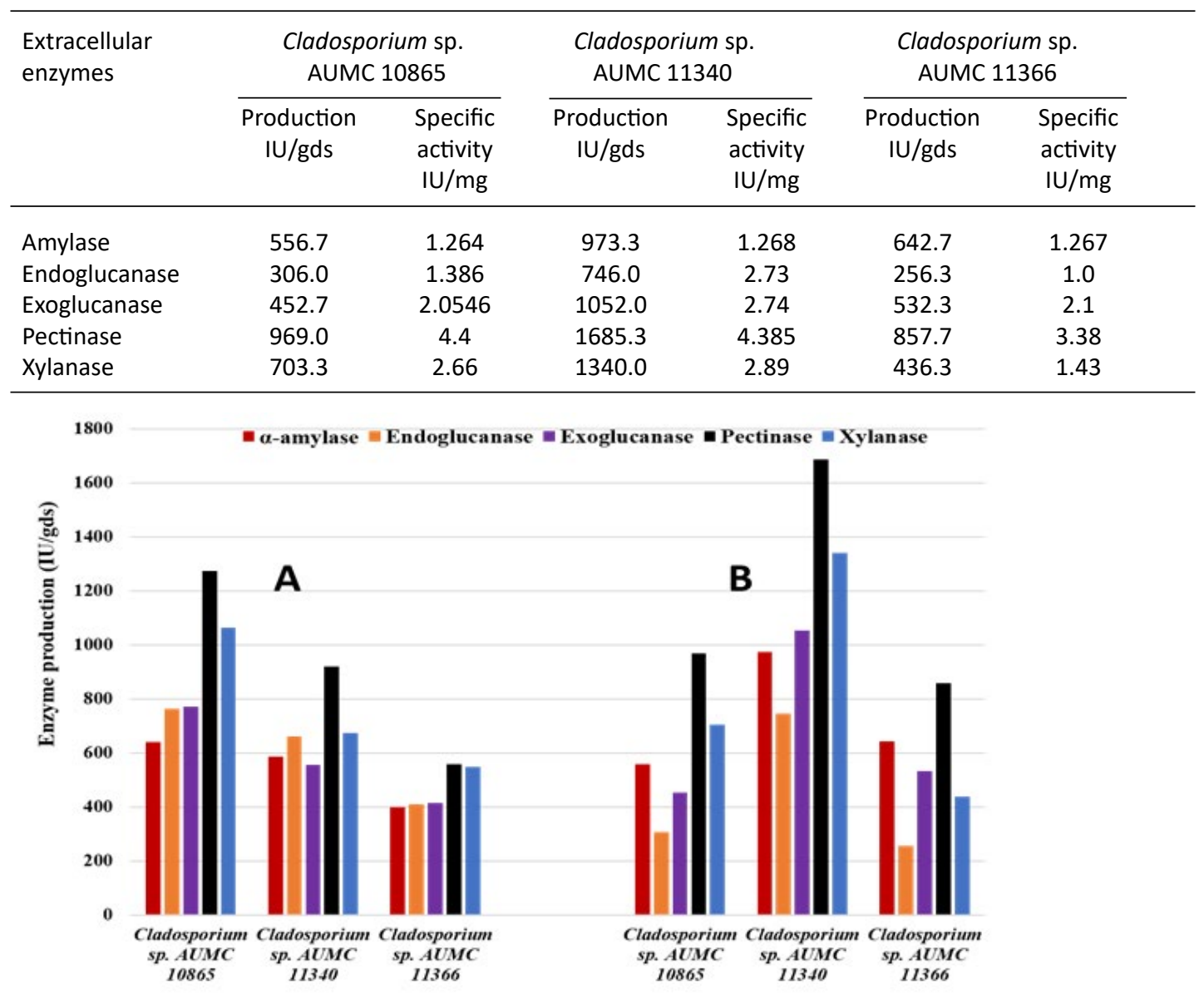

Fig. 4. Enzyme production by Cladosporium isolates AUMC 10865, AUMC 11340 and AUMC 11366 from fresh orange peels in SSF at $10^{\circ} \mathrm{C}(\mathrm{A})$ and $30^{\circ} \mathrm{C}(\mathrm{B})$. 
11366 produced the least endoglucanase $(256.3$ IU/gds), pectinase (857.7 IU/gfs) and xylanase (436.3 IU/gds) amounts (Table 4; Fig. 4).

\section{DISCUSSION}

All living systems contain enzymes, which act as biological catalysts. ${ }^{39,40}$ Enzymes are proteins in origin and catalyse a wide range of biological processes. Enzymes have been employed in several industries such as wine, cheese, bread, beer, vinegar, leather and linen. ${ }^{41,42}$ In this study, three Cladosporium species were isolated from air and grapevine fruits. It was determined that the three isolates could not be identified based just on ITS sequencing, and that they may require sequencing of other genes such as actin (ACT), elongation factor 1-alpha (EF1), and large subunit (LSU) in order to be positively identified.

The enzymatic activity of the three Cladosporium species was assessed. With the aid of SmF, all isolates were able to produce different quantities of amylase, endoglucanase, exoglucanase, pectinase, and xylanase enzymes. In this context, numerous studies have shown that Cladosporium species can generate a variety of enzymes, including glucoamylase by Cladosporium gossypiicola, ${ }^{43}$ laccase, cellulases, and hemicellulases by $C$. cladosporioides, ${ }^{44,45}$ alpha-amylase, cellulase, and xylanase from $C$. cladosporioides, ${ }^{46}$ and amylase, endoglucanase, exoglucanase and xylanase by $C$. allicinum AUMC 14511. ${ }^{9}$

Cladosporium isolates in this study were used in SSF to convert orange peel wastes into valuable extracellular enzymes by fermenting the wastes. At $10^{\circ} \mathrm{C}$, the isolate AUMC 10865 was superior to the other two isolates in the ability to produce the five extracellular enzymes from orange peels in SSF, while the isolate AUMC 11340 was the strongest at $30^{\circ} \mathrm{C}$ for all enzymes assayed. Orange peel waste has been shown to contain $16.9 \%$ soluble sugar, $9.21 \%$ cellulose, $10.5 \%$ hemicellulose, and $42.5 \%$ pectin, ${ }^{18}$ which may be the explanation for the high enzyme production utilizing orange peels.

Microorganisms that have evolved to cold temperatures have a lot of promise in biotechnological applications, such as waste treatment and bioremediation at lower temperatures, as well as the textile and food sectors. ${ }^{47-49}$ Cold-adaptive enzymes produced by psychrophilic microorganisms such as Cladosporium species have significant goals in bioconversion processes because of their high activity at low and moderate temperatures, they have the potential to economize processes by saving energy, and thus offer potential economic and environmental benefits such as reducing heatsensitive substrate alteration and the production of harmful by-products due to mild industrial conditions at low temperatures, and using psychrophilic enzymes. The aforementioned will make industrial operations more easy and safe, as in the case of conventional industry. ${ }^{48,50}$

Using Cladosporium species as enzyme developers, the current work demonstrated a lowcost substrate that does not require pretreatment. The expense of enzymes in industrial processes is a major problem. In addition, the usage of enzymes in diverse industrial processes indirectly influences the final product's price. Plant equipment and installation expenses account for a substantial percentage of an enzyme manufacturing facility's annual operating costs. ${ }^{51}$

As a means of producing industrially significant enzymes, SSF offers numerous economic benefits. For the synthesis of fungal enzymes ${ }^{52}$ and $^{53}$ have indicated that the SSF method is the most suited due to its high productivity, ease of enzyme recovery, and cost efficiency. Due to their cheap cost of collection, agro-industrial wastes are not only inexpensive solid substrates, but they are also ideal for extracellular enzyme synthesis. ${ }^{54}$ The current study, on the other hand, revealed that SmF was the best for the synthesis of all enzymes examined. The increased productivity of submerged fermentation over solid state fermentation may be ascribed to more substrate availability in SmF due to improved aeration, and the surface of the substrate particles is routinely more susceptible to enzyme action than in solid state. Furthermore, the heat transmission and homogeneity of the submerged fermentation media make it preferable to the non-homogeneous solid state.

\section{CONCLUSION}

As part of this study, three Cladosporium isolates from air and grapevine fruits in Egypt were evaluated for their enzyme activity, as well as the 
bioconversion of orange peel wastes as a low-cost substrate for SSF's extracellular enzymes. Amylase, endoglucanase, exoglucanase, pectinase and xylanase were all produced at varying quantities by the isolates when grown in SmF and SSF.

\section{ACKNOWLEDGMENTS}

None.

\section{CONFLICT OF INTEREST}

The authors declare that there is no conflict of interest

\section{FUNDING}

None.

\section{AUTHORS' CONTRIBUTION}

$A M M$ and $A A Z$ conceived this project. MAM isolated the fungi. AEH and OAMSA-B performed phylogenetic analysis. OAMSA-B and MAM performed the enzymatic activity and bioconversion experiment. All authors have read and agreed to the published version of the manuscript.

\section{DATA AVAILABILITY}

All datasets generated or analyzed during this study are included in the manuscript.

\section{ETHICS STATEMENT}

This article does not contain any studies with human participants or animals performed by any of the authors.

\section{REFERENCES}

1. Bensch K, Braun U, Groenewald JZ, Crous PW. The genus Cladosporium. Studies in Mycology. 2012;72:1401. doi: $10.3114 /$ sim0003

2. Ellis MB. More dematiaceous hyphomycetes. Commonwealth Mycological Institute, Kew, Surrey, England. $1976 ; 507$

3. Yehia RS, Osman GH, Assaggaf H, Salem R, Mohamed MS. Isolation of potential antimicrobial metabolites from endophytic fungus Cladosporium cladosporioides from endemic plant Zygophyllum mandavillei. South African Journal of Botany. 2020;134:296-302. doi: 10.1016/j.sajb.2020.02.033

4. Moubasher A. Soil fungi in Qatar and other Arab countries. The Centre for Scientific and Applied Research, University of Qatar; 1993.

5. Ismail M, Moubasher A, Mohamed R, Al-Bedak $O$. Extremophilic fungi and chemical analysis of hypersaline, alkaline lakes of Wadi-El-Natrun, Egypt.
International Journal of Technical Research and Science. 2017;1(10):345-363.

6. Farr DF, Bills GF. Chamuris GP, Rossman AY. Fungi on plants and plant products in the United States. APS press; 1989. doi: 10.1002/fedr.19901010703

7. Flannigan B, Samson RA, Miller JD. Microorganisms in home and indoorwork environments: diversity, health impacts, investigation and control. 1st edition, CRC Press; 2002.

8. Flannigan B, Samson RA, Miller JD. Microorganisms in home and indoor work environments: diversity, health impacts, investigation and control. CRC Press; 2011. doi: 10.1201/b10838

9. Al-Bedak OA, Teama EA, Ali E, Said M, Shalaby E, Moharram ZA. Impact of fumigation with phosphine on viability of wheat grains stored for six months at two levels of moisture content, in addition to description of four new records of associated fungi and assessment of their potential for enzymatic production. Journal of Basic \& Applied Mycology (Egypt). 2020;11:77-97.

10. Schubert K, Braun U. Taxonomic revision of the genus Cladosporium s. lat. 2. Cladosporium species occurring on hosts of the families Bignoniaceae and Orchidaceae. Sydowia. 2004;56(2):296-317.

11. Heuchert B, Braun U, Schubert K. Morphotaxonomic revision of fungicolous Cladosporium species (hyphomycetes). Schlechtendalia. 2005;13:1-78.

12. Martin M, Siles J, Chica A, Martin A. Biomethanization of orange peel waste. Bioresource Technology. 2010;101(23):8993-8999. doi: 10.1016/j. biortech.2010.06.133

13. Embaby AM, Masoud AA, Marey HS, Shaban NZ, Ghonaim TM. Raw agro-industrial orange peel waste as a low cost effective inducer for alkaline polygalacturonase production from Bacillus licheniformis SHG10. Springer Plus. 2014;3(1):327. doi: 10.1186/2193-1801-3-327

14. Mohamed SA, Drees EA, El-Badry MO, Fahmy AS. Biochemical Properties of $\alpha$-Amylase from Peel of Citrus sinensis cv. Abosora. Appl Biochem Biotechnol. 2010;160(7):2054-2065. doi: 10.1007/s12010-0098864-9

15. Wilkins MR, Suryawati L, Maness NO, Chrz D. Ethanol production by Saccharomyces cerevisiae and Kluyveromyces marxianus in the presence of orange-peel oil. World J Microbiol Biotechnol. 2007;23(8):1161-1168. doi: 10.1007/s11274-0079346-2

16. Li P-J, Xia J-L, Shan Y, et al. Optimizing production of pectinase from orange peel by Penicillium oxalicum PJ02 using response surface methodology. Waste and Biomass Valorization. 2015;6(1):13-22. doi: 10.1007/ s12649-014-9317-4

17. Martin M, Fernandez R, Serrano A, Siles J. Semicontinuous anaerobic co-digestion of orange peel waste and residual glycerol derived from biodiesel manufacturing. Waste Management. 2013;33(7):16331639. doi: 10.1016/j.wasman.2013.03.027

18. Rivas B, Torrado A, Torre P, Converti A, Dominguez JM. Submerged citric acid fermentation on orange peel autohydrolysate. J Agric Food Chem. 2008;56(7):23802387. doi: 10.1021/jf073388r 
19. Moller M, Schmitz P, Thiele H, Wronka T. Economically and ecologically integrated valuation of land-use in less favored areas. Ber Landwirtsch. 2001;79(1):19-48.

20. Balu AM, Budarin V, Shuttleworth PS, et al. Valorisation of orange peel residues: waste to biochemicals and nanoporous materials. Chem Sus Chem. 2012;5(9):1694-1697. doi: 10.1002/cssc.201200381

21. Flannigan B. Air sampling for fungi in indoor environments. Journal of Aerosol Science. 1997;28(3):381-392. doi: 10.1016/S00218502(96)00441-7

22. Berry ED, Wells JE. A direct plating method for estimating populations of Escherichia coli 0157 in bovine manure and manure-based materials. Journal of Food Protection. 2008;71(11):2233-2238. doi: 10.4315/0362-028X-71.11.2233

23. Al-Bedak OA, Sayed RM, Hassan SH. A new low-cost method for long-term preservation of filamentous fungi. Biocatal Agric Biotechnol. 2019;22:101417. doi: 10.1016/j.bcab.2019.101417

24. Moubasher A, Ismail M, Al-Bedak O, Mohamed R. Ramophialophora chlamydospora, a new species from an alkaline lake of Wadi-El-Natron, Egypt. Asian J Mycol. 2019;2(1):110-117. doi: 10.5943/ajom/2/1/5

25. White TJ, Bruns T, Lee $S$, Taylor J. Amplification and direct sequencing of fungal ribosomal RNA genes for phylogenetics. PCR protocols: a guide to methods and applications. 1990;18(1):315-322. doi: 10.1016/B9780-12-372180-8.50042-1

26. Al-Bedak O, Moubasher A. Aspergillus gaarensis, a new addition to section Circumdati from soil of Lake El-Gaar in Wadi-El-Natron, Egypt. Studies in Fungi. 2020;5(1):59-65. doi: 10.5943/sif/5/1/5

27. Katoh K, Standley DM. MAFFT multiple sequence alignment software version 7: improvements in performance and usability. Mol Biol Evol. 2013;30(4):772-780. doi: 10.1093/molbev/mst010

28. Criscuolo A, Gribaldo S. BMGE (Block Mapping and Gathering with Entropy): a new software for selection of phylogenetic informative regions from multiple sequence alignments. BMC Evol Biol. 2010;10(1):210. doi: 10.1186/1471-2148-10-210

29. Guindon S, Dufayard J-F, Lefort V, Anisimova M, Hordijk W, Gascuel O. New algorithms and methods to estimate maximum-likelihood phylogenies: assessing the performance of PhyML 3.0. Systematic Biology. 2010;59(3):307-321. doi: 10.1093/sysbio/syq010

30. Felsenstein J. Confidence limits on phylogenies: an approach using the bootstrap. Evolution. 1985;39(4):783-791. doi: 10.2307/2408678

31. Hesham AEL. New safety and rapid method for extraction of genomic DNA from bacteria and yeast strains suitable for PCR amplifications. J Pure Appl Microbiol. 2014;8(1):383-388.

32. Lefort V, Longueville J-E, Gascuel O. SMS: smart model selection in PhyML. Mol Biol Evol. 2017;34(9):24222424. doi: $10.1093 / \mathrm{molbev} / \mathrm{msx} 149$

33. Kumar S, Stecher G, Li M, Knyaz C, Tamura K. MEGA $\mathrm{X}$ : molecular evolutionary genetics analysis across computing platforms. Mol Biol Evol. 2018;35(6):15471549. doi: $10.1093 / \mathrm{molbev} / \mathrm{msy} 096$

34. Miller GL. Use of dinitrosalicylic acid reagent for determination of reducing sugar. Analytical Chemistry. 1959;31(3):426-428. doi: 10.1021/ac60147a030

35. Ghose T, Bisaria VS. Measurement of hemicellulase activities: Part I Xylanases. Pure Appl Chem. 1987;59(12):1739-1751. doi: 10.1351/ pac198759121739

36. Lowry OH, Rosebrough NJ, Farr AL, Randall RJ. Protein measurement with the Folin phenol reagent. Journal of Biological Chemistry. 1951;193:265-275. doi: 10.1016/ S0021-9258(19)52451-6

37. Moubasher A, Ismail M, Mohamed RA, Al-Bedak O. Xylanase and cellulase production under extreme conditions in submerged fermentation by some fungi isolated from hypersaline, alkaline lakes of Wadi-ElNatrun, Egypt. J Basic Appl Mycol. 2016;7:19-32.

38. AL-Kolaibe AM, Moharram AM, Al-Bedak OA. Worthwhile enzyme production and eco-friendly bioconversion of three agricultural residues by Aspergillus curvatus and Aspergillus gaarensis, promising enzyme-producers isolated from extreme environment. Journal of Basic \& Applied Mycology (Egypt). 2021;12:1-14.

39. Hesham AEL, Alrumman SA, Al-Dayel MA, Salah HA. Screening and genetic identification of acidic and neutral protease-producing yeasts strains by $26 \mathrm{~S}$ rRNA gene sequencing. Cytology and Genetics. 2017;51(3):221229. doi: 10.3103/S0095452717030033

40. Salah HA, Temerk HA, Salah NA, et al. Production and Optimization of Xylanase and $\alpha$-Amylase from NonSaccharomyces Yeasts (Pichia membranifaciens). J Pure Appl Microbiol. 2021;15(1):452-461. doi: 10.22207/ JPAM.15.1.43

41. Ravindran R, Jaiswal AK. Microbial enzyme production using lignocellulosic food industry wastes as feedstock: a review. Bioengineering. 2016;3(4):30. doi: 10.3390/ bioengineering 3040030

42. Adrio JL, Demain AL. Microbial enzymes: tools for biotechnological processes. Biomolecules. 2014;4(1):117-139. doi: 10.3390/biom4010117

43. Quigley T, Kelly C, Doyle E, Fogarty W. Patterns of raw starch digestion by the glucoamylase of Cladosporium gossypiicola ATCC 38026. Process Biochemistry. 1998;33(6):677-681. doi: 10.1016/ S0032-9592(98)00036-3

44. Aslam MS, Aishy A, Samra ZQ, Gull I, Athar MA. Identification, purification and characterization of a novel extracellular laccase from Cladosporium cladosporioides. Biotechnol Biotechnol Equip. 2012;26(6):3345-3350. doi: 10.5504/BBEQ.2012.0107

45. Halaburgi VM, Sharma S, Sinha M, Singh TP, Karegoudar TB. Purification and characterization of a thermostable laccase from the ascomycetes Cladosporium cladosporioides and its applications. Process Biochemistry. 2011;46(5):1146-1152. doi: 10.1016/j.procbio.2011.02.002

46. Mushimiyimana I. A statistical strategy for the production of cellulase, xylanase and $\alpha$-amylase by Cladosporium cladosporioides. Fungal Territory. 2019;2(2):16-21. doi: 10.36547/ft.2019.2.2.16-21

47. Ji L, Yang J, Fan $\mathrm{H}$, et al. Synergy of crude enzyme cocktail from cold-adapted Cladosporium cladosporioides Ch22 with commercial xylanase achieving high sugars yield 
at low cost. Biotechnology for Biofuels. 2014;7(1):130. doi: 10.1186/s13068-014-0130-x

48. Kasana RC, Gulati A. Cellulases from psychrophilic microorganisms: a review. J Basic Microbiol. 2011;51(6):572-579. doi: 10.1002/jobm.201000385

49. Margesin R, Schinner F. Properties of coldadapted microorganisms and their potential role in biotechnology. J Biotechnol. 1994;33(1):1-14. doi: 10.1016/0168-1656(94)90093-0

50. Hamid B, Rana RS, Chauhan D, et al. Psychrophilic yeasts and their biotechnological applications-a review. African J Biotechnol. 2014;13(22):2188-2197. doi: 10.5897/AJB2014.13644

51. Klein-Marcuschamer D, Oleskowicz-Popiel P, Simmons $B A, B l a n c h ~ H W$. The challenge of enzyme cost in the production of lignocellulosic biofuels. Biotechnology and Bioengineering. 2012;109(4):1083-1087. doi: 10.1002/bit.24370

52. Pandey A, Soccol CR, Nigam P, Soccol VT. Biotechnological potential of agro-industrial residues. I: sugarcane bagasse. Bioresource Technology. 2000;74(1):69-80. doi: 10.1016/S0960-8524(99)00142-X

53. Viniegra-Gonzalez G, Favela-Torres E, Aguilar CN, de Jesus Romero-Gomez S, Diaz-Godınez G, Augur C. Advantages of fungal enzyme production in solid state over liquid fermentation systems. Biochemical Engineering Journal. 2003;13(2-3):157-167. doi: 10.1016/S1369-703X(02)00128-6

54. Mahmoodi M, Najafpour G, Mohammadi M. Bioconversion of agroindustrial wastes to pectinases enzyme via solid state fermentation in trays and rotating drum bioreactors. Biocatal Agric Biotechnol. 2019;21:101280. 